\title{
Sildenafil for Asian Adult Patients with Pulmonary Arterial Hypertension: A Systematic Review and Meta-analysis
}

\section{Qianling Shi}

Lanzhou University First Affiliated Hospital

\section{Zijun Wang}

Lanzhou University School of Basic Medical Sciences

\section{Nan Yang}

Lanzhou University School of Basic Medical Sciences

\section{Yanfang Ma}

Lanzhou University School of Basic Medical Sciences

\section{Yaolong Chen}

Lanzhou University School of Basic Medical Sciences

Hua Yao ( $18119372718 @ 163 . c o m$ )

Guangdong Provincial People's Hospital

\section{Research}

Keywords: Sildenafil, Pulmonary arterial hypertension, Systematic review, Meta-analysis

Posted Date: May 10th, 2021

DOI: https://doi.org/10.21203/rs.3.rs-498117/v1

License: (c) (i) This work is licensed under a Creative Commons Attribution 4.0 International License. Read Full License 


\section{Abstract}

Background: The prognosis of patients with untreated pulmonary arterial hypertension (PAH) has historically been poor. Previous studies have recommended that sildenafil was beneficial, but the dose varies greatly. We aimed to evaluate sildenafil effectiveness and safety in dose of $20 \mathrm{mg} /$ three times a day (TID) for Asian adult patients with $\mathrm{PAH}$.

Methods: Electronic databases (MEDLINE, Embase, Web of Science, the Cochrane Library, CBM, CNKI and Wanfang Data) from their inception to May 2020 were searched. We included all randomized controlled trials and nonrandomized studies of interventions that comparing sildenafil (20mg/TID) versus placebo or symptomatic treatment for PAH Asian adults.

Results: Eight studies totaling 364 participants were included. When compared to symptomatic treatment, sildenafil treated patients were more likely to walk 68.3 meters further in six-minute walk distance [mean difference $(M D)=68.3$ meters, 95\% confidence interval (CI) 48.85 to 87.76, $P \otimes 0.00001]$, to achieve an improvement in systemic arterial oxygen saturation ( $\mathrm{MD}=2.48 \%, 95 \% \mathrm{Cl} 1.26$ to $3.71, P \otimes 0.00001)$ and in score on the Borg scale of dyspnea (MD=-0.99 points, $95 \% \mathrm{Cl}-1.45$ to $-0.53, P \otimes 0.00001)$. The total number of patients with WHO class III and IV also showed downtrend. When compared to placebo, sildenafil was associated with a greater reduction in the mean pulmonary artery pressure $(\mathrm{MD}=-4.13 \mathrm{mmHg}, 95 \% \mathrm{Cl}-6.52$ to $-1.74, P=0.0007)$ and level of brain natriuretic peptide (MD=-86.16 $\mathrm{pg} / \mathrm{mL}, 95 \% \mathrm{Cl}-103.39$ to $-68.93, P \otimes 0.00001)$. The most adverse reactions were headache, flushing, dyspepsia, and diarrhea, which were relatively mild.

Conclusions: Sildenafil in dose of $20 \mathrm{mg} /$ TID is well tolerated in Asian adults with PAH, and associated with statistically significant improvements in exercise capacity, cardio-pulmonary function and haemodynamic indices. The long-term prognosis still needs to be evaluated and confirmed by further trials.

\section{Systematic review registration: PROSPERO CRD42020190582}

\section{Background}

Pulmonary hypertension $(\mathrm{PH})$ is a group of complex conditions characterized by progressive increase in pulmonary artery pressure (PAP) with or without irreversible vascular remodeling, leading to right ventricular failure and premature death. Present estimates suggest a $\mathrm{PH}$ prevalence of about $1 \%$ of the global population, which increases up to $5-10 \%$ in individuals aged more than 65 years ${ }^{[1-2]}$. According to the clinical presentations, pathophysiological and haemodynamic characteristics, $\mathrm{PH}$ can be classified into five groups, of which, pulmonary arterial hypertension $(\mathrm{PAH})$ is a group of diseases where $\mathrm{PH}$ occurs in the setting of increased pulmonary vascular resistance (PVR) ${ }^{[3-5]}$. The overall estimated rate of $\mathrm{PAH}$ was 10 to 52 per million of the population ${ }^{[6]}$, and reported incidence and prevalence for developed world is 1.1 to 7.6 and 6.6 to 26.0 per million adults per year ${ }^{[7-9]}$. For patients without effective interventions, PAH can be hugely devastating and exert an adverse impact on all aspects of life. The prognosis was once very poor with a median survival of only 2.8 years ${ }^{[10-11]}$. Recent years have seen the introduction of targeted medications to enhance survival rate with an improvement in the one-year from $69-85 \%$ and five-year from $38-57 \%[12-14]$.

Sildenafil was first approved for the treatment of PAH since 2005 by both the Food and Drug Administration (FDA) and the European Medicines Agency (EMA) for oral administration at a dose of $20 \mathrm{mg} /$ three times a day (TID). It specifically reduces the activity of cGMP degrading enzyme, thereby increasing the antiproliferative and vasodilating 
effects of endogenous NO ${ }^{[4,15]}$. Due to the reliable efficacy, good tolerability and affordability (the average cost in the United States for 1 year of treatment with sildenafil $20 \mathrm{mg} /$ TID [13, 000 dollars] compares favorably with bosentan [annual cost, 40, 000 dollars]), sildenafil has become the drug of choice for PAH patients with World Health Organization (WHO) II or III functional class. and was recommended in several guidelines ${ }^{[4,16-19]}$. Although a number of systematic reviews have confirmed its short-term clinical efficacy ${ }^{[15,20-21]}$, the dose varies greatly and they did not focus on Asian population and other important outcomes. Especially for China, iloprost and bosentan were approved for the treatment of PAH, but few patients have been treated with these agents, because the cost of one-month supply of bosentan and iloprost [3,000 dollars] is much more than sildenafil 20mg/TID [300 dollars] per month, which was approved recently ${ }^{[22]}$. Therefore, the purpose of this study is to quantify effectiveness and safety of sildenafil (20mg/TID) for adult PAH patients in Asia in order to provide guidance for patient preference, clinician treatment choices and guidelines development.

\section{Methods}

This systematic review was conducted in accordance with the Preferred Reporting Items for Systematic Review and Meta-Analysis (PRISMA) standards ${ }^{[23]}$ and PRISMA extension for literature searches ${ }^{[24]}$ (Additional file 1). Our protocol was registered in PROSPERO (registration number CRD42020190582).

\section{Data sources and searches}

Two researchers (S.Q.L.and W.Z.J.) independently searched the following databases up to 3 May 2020: MEDLINE (via PubMed), Embase, Web of Science, The Cochrane Library, China Biology Medicine (CBM), China National Knowledge Infrastructure (CNKI) and Wanfang Data ${ }^{[25]}$. We also searched clinical trial registry platforms (US National Institutes of Health Trials Register and WHO Clinical Trials Registry Platform), Google Scholar, and reference lists of retrieved articles to identify studies that may have been missed.

The search strategy was also peer reviewed by an external specialist. We systematically searched by combining the $\mathrm{MeSH}$ and free words. The keywords and terms in the MEDLINE included "sildenafil”, "Pulmonary Arterial Hypertension", "PAH" and their derivatives. The details of search strategies can be found in the Additional file 2.

\section{Inclusion and exclusion criteria}

\section{Types of studies}

We included all randomized controlled trials (RCTs) and non-randomized studies of interventions (NRSIs) that compared effectiveness and safety of sildenafil (20mg/TID) with placebo, or comparing the combination of sildenafil (20mg/TID) and symptomatic treatment with symptomatic treatment alone. Considering that PAH is a rare disease and there maybe few studies, we also included multi-center RCTs and NRSIs involving Asian adult PAH patients. In vitro studies, animal experiments and basic researches were excluded. Duplicates, articles written in languages other than English or Chinese, conference abstracts were also excluded.

\section{Types of participants}

We included any Asian adult patient with a diagnosis of $\mathrm{PAH}$ who required medical treatment for their condition. We defined PAH as a mean PAP equal to or more than $25 \mathrm{mmHg}$ by right-heart catheterisation according to accepted criteria ${ }^{[3,17-18]}$, and included the following categories: (1) idiopathic $\mathrm{PAH}$; (2) PAH with vasoreactivity; (3) heritable $\mathrm{PAH}$; (4) drugs and toxins related PAH; (5) PAH associated with connective tissue disease (CTD), HIV, portal 
hypertension, congenital heart disease (CHD) and schistosomiasis; (6) pulmonary veno-occlusive disease or pulmonary capillary haemangiomatosis.

\section{Types of outcome measures}

The primary outcomes were six-minute walk distance (6MWD), dyspnoea score on any scale, level of brain natriuretic peptide (BNP), change in WHO functional class, mean PAP, systemic arterial oxygen saturation and adverse events. The secondary outcomes included but not limited to haemodynamic parameters (right atrium pressure [RAP], PVR, cardiac index [CI]), quality of life, time to clinical worsening, incidence of clinical worsening and mortality.

\section{Study selection}

After eliminating duplicates, two researchers (S.Q.L.and W.Z.J.) independently screened the titles, abstracts, and fulltexts of potentially relevant articles, using pre-defined criteria. The specific bibliographic software EndNote X9 was used. Discrepancies were discussed, or solved with a third researcher (Y.N.). All reasons for excluding ineligible studies were recorded. The process of study selection was documented using a PRISMA flow diagram [23].

\section{Data extraction}

Two researchers (S.Q.L.and W.Z.J.) extracted data independently with a pre-determined data collection form. Disagreements were resolved by discussion. We extracted the following data: (1) methods: first author, study design, study setting, number of study centres and location; (2) participants: sample, age, gender, diagnostic criteria, important baseline data, inclusion and exclusion criteria; (3) intervention: dose, mode of administration and control measures; (4) outcomes: primary and secondary outcomes as specified, type of scale used, time points collected (for dichotomous data, the number of events and total participants in per group; for continuous data, means, standard deviations (SD), and the number of total participants in per group); (5) characteristics of trial design as outlined in the "risk of bias assessment in included studies" section; (6) other: funding and conflicts of interest for trial authors.

\section{Risk of bias assessment}

Four researchers (S.Q.L., W.Z.J., Y.N. and M.Y.F.) assessed the risk of bias for included studies independently in pairs. Discrepancies were resolved by discussion. For RCTs, we used the Cochrane Risk-of-Bias assessment tool [26], and graded each bias as low risk, unclear risk (insufficient information to form a judgement) or high risk. For NRSIs, we

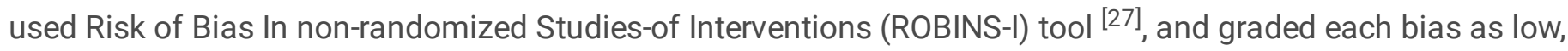
moderate, serious, critical and no information.

\section{Data analysis}

We performed Meta-analysis of outcomes for which the data were sufficiently compatible. For dichotomous data, we calculated odds ratio (OR) with 95\% confidence intervals (CI); for continuous data, we calculated mean difference (MD) or standardized mean difference (SMD) with $95 \% \mathrm{Cl}$, depending on whether the same scale is used to measure an outcome. Analyses were performed by Review Manager 5.3 software. We used a fixed-effects model, and the level of statistical significance was set at $P<0.05$ with two-sided. If both data from baseline and endpoint scores were available for continuous data, we used change from baseline scores. Missing data were obtained by graphical software or other means ${ }^{[28-29]}$.

We quantified statistical heterogeneity using the $\mathrm{I}^{2}$ statistic, and considered that a $0 \%$ value indicated no heterogeneity, and higher values of $25 \%, 50 \%$, and $75 \%$ represented increasing levels of low, moderate, and high, respectively. An $\mathrm{I}^{2}$ less than $50 \%$ was considered as acceptable. If we detected high heterogeneity, we conducted 
subgroup or sensitivity analysis, then random-effects model would be used ${ }^{[28,30]}$. Where sufficient studies were present, we planned to assess publication bias by examining the symmetry of the funnel plot ${ }^{[28]}$.

\section{Results}

\section{Results of the search}

We identified 9,806 references from the databases, and three records from additional searches. A total of 2,919 records were excluded as duplicates. After screening for titles and abstracts, we selected 94 studies for full-text review. Finally, a total of eight studies (five RCTs and three NRSIs) with 364 patients were included (see Fig. 1) $[22,31-37]$.

\section{Study and patient characteristics}

Characteristics of included studies and patients are illustrated in Table 1. These studies were published between 2005 and 2015 and the sample size ranged from 21 to 139, of which, sildenafil was all administered orally with $20 \mathrm{mg} /$ TID. Most studies recruited participants with WHO functional class II and III. The etiologies of majority were idiopathic PAH, PAH associated with CTD and CHD. Included studies were conducted for 20 weeks on average. 
Table 1

Baseline characteristics of included studies

\begin{tabular}{|c|c|c|c|c|c|c|c|c|c|c|}
\hline \multirow[t]{2}{*}{ Study ID } & \multirow{2}{*}{$\begin{array}{l}\text { Study } \\
\text { Type }\end{array}$} & \multirow{2}{*}{$\begin{array}{l}\text { Etiology } \\
(\%)\end{array}$} & \multirow[t]{2}{*}{ Sample } & \multirow[t]{2}{*}{$\operatorname{Age}(T / C) *$} & \multicolumn{4}{|c|}{ WHO functional class (\%) } & \multirow{2}{*}{$\begin{array}{l}\text { Follow } \\
\text { up }\end{array}$} & \multirow{2}{*}{$\begin{array}{l}\text { Outcomes } \\
t\end{array}$} \\
\hline & & & & & I & II & III & IV & & \\
\hline $\begin{array}{l}\text { Galiè } \\
2005^{[31]}\end{array}$ & $\mathrm{RCT}$ & $\begin{array}{l}\text { IPAH } \\
(61.87) \\
\\
\text { CTD- } \\
\text { PAH } \\
(30.94) \\
\text { CHD- } \\
\text { PAH } \\
(7.19)\end{array}$ & 139 & $\begin{array}{l}47 \pm \\
14 / 49 \pm \\
17\end{array}$ & 0.72 & 40.29 & 53.24 & 5.76 & $12 W$ & 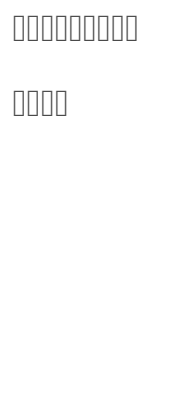 \\
\hline $\begin{array}{l}\text { Pepke- } \\
\text { Zaba } \\
2008^{[32]}\end{array}$ & $\mathrm{RCT}$ & NR & NR & NR & NR & & & & $12 \mathrm{~W}$ & $\mathrm{Qu}$ \\
\hline $\begin{array}{l}\text { Xu } \\
2009^{[22]}\end{array}$ & NRSI & $\begin{array}{l}\text { IPAH } \\
(66.67) \\
\text { CHD- } \\
\text { PAH } \\
(20.00) \\
\text { CTD- } \\
\text { PAH } \\
(13.33)\end{array}$ & 60 & $\begin{array}{l}33.56 \pm \\
14.12\end{array}$ & 0 & 43.33 & 53.34 & 3.33 & $16 \mathrm{~W}$ & 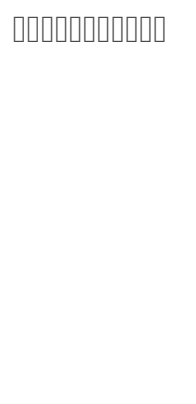 \\
\hline $\begin{array}{l}\text { Zhang } \\
2011^{[33]}\end{array}$ & NRSI & $\begin{array}{l}\text { CHD- } \\
\text { PAH } \\
(100.00)\end{array}$ & 84 & $28 \pm 9$ & 0 & 52 & 39 & 8 & $12 \mathrm{M}$ & 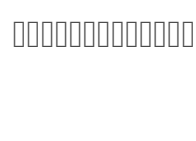 \\
\hline $\begin{array}{l}\text { Satoh } \\
2011^{[34]}\end{array}$ & NRSI & $\begin{array}{l}\text { IPAH } \\
(28.57) \\
\text { FPAH } \\
(23.81) \\
\text { APAH } \\
(47.62 \%)\end{array}$ & 21 & $\begin{array}{l}47.1 \pm \\
14.7\end{array}$ & 0 & 31.80 & 36.60 & 0 & $12 \mathrm{~W}$ & 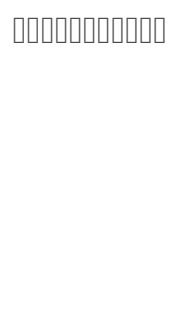 \\
\hline $\begin{array}{l}\text { Wirostko } \\
2012^{[35]}\end{array}$ & RCT & $\begin{array}{l}\text { IPAH } \\
(61.87) \\
\\
\text { CTD- } \\
\text { PAH } \\
(30.94) \\
\text { CHD- } \\
\text { PAH } \\
(7.19)\end{array}$ & 139 & $\begin{array}{l}47 \pm \\
14 / 49 \pm \\
17\end{array}$ & 0.72 & 40.29 & 53.24 & 5.76 & $12 W$ & प \\
\hline $\begin{array}{l}\mathrm{Xu} \\
2013^{[36]}\end{array}$ & $\mathrm{RCT}$ & NR & 42 & $\begin{array}{l}33.7 \pm \\
14.3\end{array}$ & NR & & & & $3 \mathrm{M}$ & प्रा \\
\hline
\end{tabular}




\begin{tabular}{|c|c|c|c|c|c|c|c|c|c|c|}
\hline \multirow[t]{2}{*}{ Study ID } & \multirow{2}{*}{$\begin{array}{l}\text { Study } \\
\text { Type }\end{array}$} & \multirow{2}{*}{$\begin{array}{l}\text { Etiology } \\
(\%)\end{array}$} & \multirow[t]{2}{*}{ Sample } & \multirow[t]{2}{*}{$\operatorname{Age}(\mathrm{T} / \mathrm{C}) *$} & \multicolumn{4}{|c|}{ WHO functional class (\%) } & \multirow{2}{*}{$\begin{array}{l}\text { Follow } \\
\text { up }\end{array}$} & \multirow{2}{*}{$\begin{array}{l}\text { Outcomes } \\
t\end{array}$} \\
\hline & & & & & 1 & II & III & IV & & \\
\hline \multirow[t]{3}{*}{$\begin{array}{l}\text { Webb } \\
2015^{[37]}\end{array}$} & \multirow[t]{3}{*}{ RCT } & $\begin{array}{l}\text { IPAH } \\
(61.87)\end{array}$ & 139 & \multirow{3}{*}{$\begin{array}{l}47 \pm \\
14 / 49 \pm \\
17\end{array}$} & \multirow[t]{3}{*}{0.72} & \multirow[t]{3}{*}{40.29} & \multirow[t]{3}{*}{53.24} & \multirow[t]{3}{*}{5.76} & \multirow[t]{3}{*}{$12 \mathrm{~W}$} & \multirow[t]{3}{*}{$\square$} \\
\hline & & $\begin{array}{l}\text { CTD- } \\
\text { PAH } \\
(30.94)\end{array}$ & & & & & & & & \\
\hline & & $\begin{array}{l}\text { CHD- } \\
\text { PAH } \\
(7.19)\end{array}$ & & & & & & & & \\
\hline \multicolumn{11}{|c|}{ 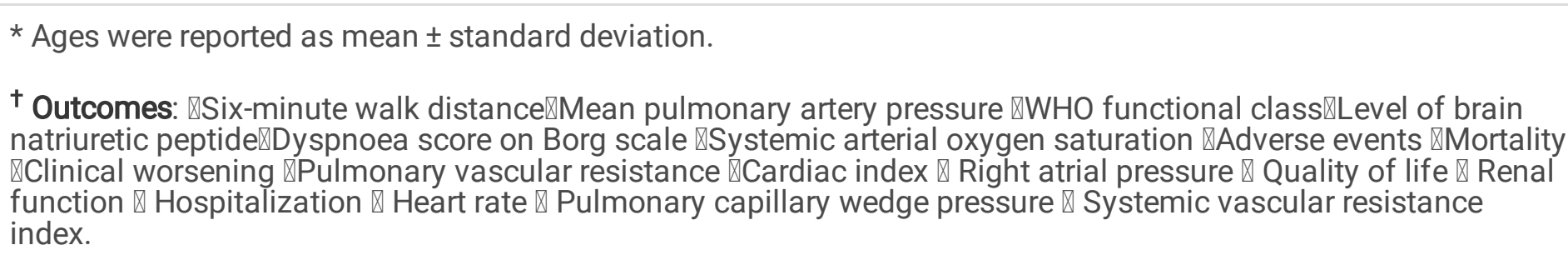 } \\
\hline \multicolumn{11}{|c|}{$\begin{array}{l}\text { Abbreviation: RCT: Randomized Controlled Trial; NRSI: Non randomized Studies of Interventions; IPAH: Idiopathic } \\
\text { Pulmonary Arterial Hypertension; CTD-PAH: Connective-Tissue Disease-Pulmonary Arterial Hypertension; CHD- } \\
\text { PAH: Congenital Heart Disease- Pulmonary Arterial Hypertension; FPAH: Familial Pulmonary Arterial Hypertension; } \\
\text { APAH: Associated with Pulmonary Arterial Hypertension; NR: Not Reported; W: Week; M: Month; T: Treatment; C: } \\
\text { Control. }\end{array}$} \\
\hline
\end{tabular}

\section{Risk of bias in included studies}

For the five RCTs, we assessed random sequence generation, allocation concealment, blinding of participants and personnel and blinding of outcomes as low risk for only one study [35]. Galiè 2005 ${ }^{[31]}$, Pepke-Zaba $2008{ }^{[32]}$, Xu 2013 ${ }^{[36]}$ and Webb $2015^{[37]}$ were at unclear risk, as they did not report the relevant methods. As for incomplete outcome data and selective reporting, all studies were assessed as low risk ${ }^{[31-32,35-37]}$. In the domain of other potential sources of bias, four studies ${ }^{[31-32,35,37]}$ received funding from Pfizer and one contained error in data ${ }^{[36]}$, so we rated all of them at high risk. For the three NRSIs, two ${ }^{[22,33]}$ were assessed as moderate risk and one ${ }^{[34]}$ was serious risk. Details can be found in Additional file 3.

\section{Clinical outcomes 6MWD}

Five studies ${ }^{[22,31-34]}$ (two RCTs and three NRSIs) evaluated 6MWD. Two studies ${ }^{[31-32]}$ which reported only $P$ values and $99 \% \mathrm{Cl}$ with significant improvement in 6MWD were excluded from the pooled analysis. In comparison with symptomatic treatment, sildenafil yielded greater improvement in 6MWD (MD $=68.3$ meters, $95 \% \mathrm{Cl} 48.85$ to 87.76 ). There was no heterogeneity between trials $\left(I^{2}=0 \%\right.$, Fig. 2$)$.

\section{Dyspnoea score}

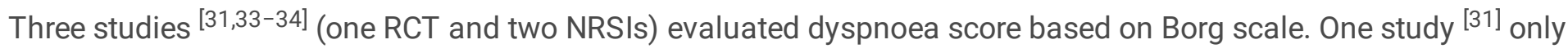
reported the change from baseline did not differ significantly from that in the placebo group with no other data available was excluded from the pooled analysis. When comparing to symptomatic treatment, sildenafil was associated with a significant decrease (reflecting improvement) in dyspnoea score (MD=-0.99 points, $95 \% \mathrm{Cl}-1.45$ to $-0.53)$. There was no heterogeneity between trials $\left(I^{2}=0 \%\right.$, Fig. 3$)$. 


\section{WHO functional class}

Four studies ${ }^{[22,31,33-34]}$ (one RCT and three NRSIs) evaluated WHO functional class. We described them in narrative form because most data were missing for Meta-analysis (Table 2). In general, when compared to placebo or symptomatic treatment, the total number of patients with WHO class III and IV in group of sildenafil showed an overall trend of decline (reflecting improvement).

Table 2

Improvement in WHO functional class

\begin{tabular}{|c|c|c|c|c|}
\hline $\begin{array}{l}\text { Study } \\
\text { ID }\end{array}$ & $\begin{array}{l}\text { Study } \\
\text { Type }\end{array}$ & Placebo/Before & Sildenafil /After & $\mathrm{P}$ \\
\hline $\begin{array}{l}\text { Galiè } \\
2005^{[31]}\end{array}$ & $\mathrm{RCT}$ & $\begin{array}{l}\text { patients with an improvement of at } \\
\text { least one functional class were } 7 \\
\text { percent }\end{array}$ & $\begin{array}{l}\text { patients with an improvement of at least } \\
\text { one functional class were } 28 \text { percent }\end{array}$ & 0.003 \\
\hline \multirow{4}{*}{$\begin{array}{l}\mathrm{Xu} \\
2009[22]\end{array}$} & \multirow[t]{4}{*}{ NRSI } & I: 0 & I: 6 & \multirow[t]{4}{*}{$\mathrm{NR}^{\star}$} \\
\hline & & II: 26 & II: 42 & \\
\hline & & III: 32 & III: 12 & \\
\hline & & IV: 2 & IV: 0 & \\
\hline \multirow{4}{*}{$\begin{array}{l}\text { Zhang } \\
2011^{[33]}\end{array}$} & \multirow[t]{4}{*}{ NRSI } & I: 0 & I: 7 & \multirow{4}{*}{$<.001$} \\
\hline & & II: 44 & II: 68 & \\
\hline & & III: 33 & III: 8 & \\
\hline & & IV: 7 & IV: 1 & \\
\hline \multirow{4}{*}{$\begin{array}{l}\text { Satoh } \\
2011^{[34]}\end{array}$} & \multirow[t]{4}{*}{ NRSI } & I: 0 & I: 1 & \multirow[t]{4}{*}{ NR } \\
\hline & & II: 7 & II: 11 & \\
\hline & & III: 14 & III: 9 & \\
\hline & & IV: 0 & IV: 0 & \\
\hline
\end{tabular}

\section{Level of BNP}

Three studies ${ }^{[22,34,36]}$ (one RCT and two NRSIs) evaluated the level of BNP. One study ${ }^{[34]}$ that only reported plasma BNP decreased from baseline was excluded from the pooled analysis. When compared to placebo or symptomatic treatment, sildenafil was associated with a decrease in level of BNP (MD=-86.16 pg /mL, 95\% Cl-103.39 to -68.93). There was not important heterogeneity between trials $\left(I^{2}=14 \%\right.$, Fig. 4).

\section{Mean PAP}

Four studies ${ }^{[22,31,33,36]}$ (two RCTs and two NRSIs) evaluated the mean PAP. When compared to placebo, sildenafil was associated with a greater reduction in mean PAP (MD $=-4.13 \mathrm{mmHg}, 95 \% \mathrm{Cl}-6.52$ to -1.74$)$. There was considerable heterogeneity between trials $\left(I^{2}=89 \%\right.$, Fig. 5$)$. We conducted sensitivity analysis by excluding one study 
${ }^{[36]}$ which involved surgery with low-quality. Results showed that sildenafil reduced mean PAP (MD $=-2.70 \mathrm{mmHg}, 95 \%$ $\mathrm{Cl}-5.26$ to -0.14). When compared to symptomatic treatment, sildenafil could reduce the mean PAP with no statistically significant difference found ( $M D=-4.90 \mathrm{mmHg}, 95 \% \mathrm{Cl}-10.36$ to 0.55 , Fig. 6).

\section{Systemic arterial oxygen saturation}

Two NRSIs ${ }^{[22,33]}$ evaluated the systemic arterial oxygen saturation. When compared with symptomatic treatment, patients received sildenafil had higher level of systemic arterial oxygen saturation (MD = 2.48 \%, 95\% $\mathrm{Cl} 1.26$ to 3.71 ). There was no heterogeneity between trials $\left(1^{2}=0 \%\right.$, Fig. 7$)$.

\section{Haemodynamic parameters other than mean PAP}

Two studies ${ }^{[22,31]}$ (one RCT and one NRSI) evaluated PVR. When compared to placebo, sildenafil was associated with a greater reduction in PVR (MD $=-171.00$ dyn.sec $\cdot \mathrm{cm}-5,95 \% \mathrm{Cl}-311.49$ to -30.51$)$. When compared to symptomatic treatment, sildenafil could decrease PVR with no statistically significant difference (MD=-1.02 Wood Units, $95 \% \mathrm{Cl}-3.73$ to 1.69$)$.

Four studies ${ }^{[22,31,33-34]}$ (one RCT and three NRSIs) evaluated RAP. When compared to symptomatic treatment, the results showed that sildenafil therapy decreased $\mathrm{RAP}(\mathrm{MD}=-1.17 \mathrm{~mm} \mathrm{Hg}, 95 \% \mathrm{Cl}-2.14$ to -0.20$)$. When compared to placebo, reduction in RAP was also observed with no statistically significant difference found (MD $=-1.10 \mathrm{~mm} \mathrm{Hg}$, $95 \% \mathrm{Cl}-2.73$ to 0.53$)$.

Three studies ${ }^{[22,31,34]}$ (one RCT and two NRSIs) evaluated CI. When compared to symptomatic treatment, the use of sildenafil improved the level of $\mathrm{Cl}\left(\mathrm{MD}=0.35 \mathrm{~L} /\left(\mathrm{min} \cdot \mathrm{m}^{2}\right), 95 \% \mathrm{Cl} 0.07\right.$ to 0.63$)$. While no statistically significant difference was observed in the level of $\mathrm{Cl}\left(\mathrm{MD}=0.23 \mathrm{~L} /\left(\mathrm{min} \cdot \mathrm{m}^{2}\right), 95 \% \mathrm{Cl}-0.18\right.$ to 0.64$)$ between sildenafil and placebo.

\section{Adverse events}

Five studies [22, 31, 33-34, 36] (two RCTs and three NRSIs) evaluated adverse events. One study that reported adverse events with no data available was excluded from the pooled analysis ${ }^{[36]}$. When compared to symptomatic treatment or placebo, there was no statistically significant difference in the risk of headache, flushing, dyspepsia, diarrhea, limb pain, skin rash (Fig. 8).

No statistically significant difference was also observed in blood pressure (systolic and diastolic) and ocular safety (including change in intraocular pressure and risk of deterioration in visual acuity). In general, sildenafil was mild and well tolerated in most patients.

\section{Long-term prognosis}

Four studies reported outcomes related to long-term prognosis. Three studies ${ }^{[22,31,33]}$ (one RCT and two NRSIs) evaluated mortality (OR 1.01, 95\% $\mathrm{Cl} 0.06$ to 16.55$)$ and incidence of clinical worsening (OR $3.36,95 \% \mathrm{Cl} 0.19$ to 60.54), when compared sildenafil to symptomatic treatment and placebo, no statistically significant difference was found.

Galiè $2005^{[31]}$ evaluated quality of life. There was a statistically significant improvement in SF-36 domains of physical functioning, general health and vitality for sildenafil treated participants when compared to placebo. 
Statistically significant improvements were also observed in terms for current health status and utility index in the EQ-5D questionnaires. Results from Webb $2015^{[37]}$ showed that sildenafil treatment improved kidney function when compared to placebo, but the difference was not statistically significant.

In addition, there was no significant difference in hospitalization, heart rate, pulmonary capillary wedge pressure and systemic vascular resistance index when compared to placebo or symptomatic treatment.

\section{Publication bias}

Due to insufficient studies for each outcome, we were unable to evaluate publication bias.

\section{Discussion}

Our systematic review identified a total of eight studies. When compared to placebo or symptomatic treatment, use of sildenafil (20mg/TID) had a clear statistical and clinical benefit for PAH patients of Asian adults in terms of 6MWD, mean PAP, systemic arterial oxygen saturation, dyspnoea score on Borg scale, level of BNP and PVR. Regarding to the safety, clinicians should be aware of headache, flushing, dyspepsia, and diarrhea, which were usually relatively mild.

According to existing guidelines ${ }^{[3,17-19]}$, PAH patients should be clearly diagnosed as soon as possible and establish treatment strategies on the basis of risk stratification. During this process, making full use of targeted drugs accounts for great importance. As one of five classes of drugs now available for PAH, PDE5 inhibitors included sildenafil, tadalafil and vardenafil ${ }^{[4,12-13]}$. Among these, both FDA and EMA recommended sildenafil be orally administered at a dose of $20 \mathrm{mg} /$ TID. Although increasing evidence suggested sildenafil therapy is beneficial [2122,39-42], the dose varies greatly. A Cochrane systematic review published in 2019 indicated that sildenafil had better therapeutic effect with lower incidence of adverse events when compared to placebo ${ }^{[16]}$. However, sildenafil in the included PAH trials was prescribed in eight hourly divided doses, with dosages ranging from 20 to 100 mg/TID [16].

In this study, we focused on $20 \mathrm{mg} / \mathrm{TID}$, and included participants who were mainly idiopathic PAH, as well as CTD and $\mathrm{CHD}$ related PAH. The results on 6MWD, mean PAP, dyspnoea score, level of BNP were similar to those identified in other systematic reviews ${ }^{[16,21-22,39-42]}$. As an important indicator for severity evaluation and prognosis ${ }^{[43]}$, previous studies have shown that there was a significant improvement in WHO functional class favouring sildenafil when comparing to placebo ${ }^{[16]}$. Our systematic review however demonstrated that four studies assessed this but with too much data missing to combine in a Meta-analysis. On the other hand, we identified gaps in the existing literature that limited our conclusions. Included studies focused less on long-term outcomes, and did not pay attention to pharmacoeconomics. When comparing to placebo, PAH participants treated with sildenafil have been proven to $23 \%$ less likely to die ${ }^{[16]}$, but results from our study indicated only three studies analysed mortality with a non-statistically significant difference found, and only one study assessed quality of life. Further trials are needed to evaluate the effectiveness of sildenafil in dose of $20 \mathrm{mg} / \mathrm{TID}$ on long-term outcomes.

In terms of safety, one of the most frequent concerns during the use of PDE5 is the risk of hypotension ${ }^{[15]}$. Although we found no statistically significant difference in systolic and diastolic blood pressure when compared to symptomatic treatment or placebo, nitrates should not be used in combination with sildenafil, especially be prudent in patients with low systemic blood pressure or presyncope ${ }^{[4,15]}$.

Considering sildenafil has been poorly studied for the treatment of adult PAH patients in Asia, we also included Sildenafil Use in Pulmonary Arterial Hypertension (SUPER) study [31-32, 35, 37], a Pfizer-sponsored randomized trial. But 
for the final included studies, the total sample size is still so small and risk of bias for methodology is high, especially in the domains of randomization, allocation concealment and blindness. Therefore, we put forward some suggestions for the further research: (1) conducting high-quality studies at the recommended dose of 20mg/TID; (2) trials should measure outcomes which are clinically relevant (e.g., mortality, quality of life and clinical worsening) so that long term effects can be established; (3) attach importance to the real-world data and evaluation of pharmacoeconomics.

This study is to our knowledge the first systematic review to summarize the evidence of sildenafil effectiveness and safety for patients with PAH at the recommended dose of $20 \mathrm{mg} / \mathrm{TID}$, which is of great importance for clinicians and patients. We focus on the Asian adult and included Chinese literatures to find research gaps. We also focus on multiple outcome measures (both short-term and long-term). This study has also several limitations. First, missing data for some outcomes and small participant samples may undermined the real effect of treatment. Second, we excluded studies other than English and Chinese, as well as conference abstract that cannot be obtained the full-text, some degree of publication bias may exist. Third, we found one study ${ }^{[36]}$ in which PAP was measured by echocardiography, although it was not right cardiac catheterization, we included it and synthesized data in the final Meta-analysis.

\section{Conclusions}

Despite data comparing sildenafil in dose of $20 \mathrm{mg} /$ TID whilst on Asian adult patients with PAH were limited by the small number of included trials, our study provides conclusive evidence that sildenafil (20mg/TID) is effective and safe. Statistically significant improvements in exercise capacity, cardio-pulmonary function and haemodynamics have been observed with mild to moderate adverse reactions and good tolerance. We suggest future trials should be large sample, high-methodological quality and pay more attention to the long-term prognosis.

\section{Abbreviations}

BNP: Brain natriuretic peptide; CHD: Congenital heart disease; Cl: Cardiac index; 95\% Cl: 95\% confidence intervals; CTD: Connective tissue disease; MD: Mean difference; NRSI: Non-randomized studies of interventions; OR: Odds ratio; PAH: Pulmonary arterial hypertension; PAP: Pulmonary artery pressure; PH: Pulmonary hypertension; PRISMA:

Preferred Reporting Items for Systematic Review and Meta-Analysis; PVR: Pulmonary vascular resistance; RAP: Right atrium pressure; RCT: Randomized controlled trials; ROBINS-I: Non-randomized Studies-of Interventions; 6MWD: Sixminute walk distance; TID: Three times a day; WHO: World Health Organization.

\section{Declarations}

\section{Availability of data and materials:}

All data generated or analysed during this study are included in this published article.

\section{Acknowledgements:}

We thank Qi Zhou, The First School of Clinical Medicine of Lanzhou University, for providing guidance and comments for our systematic review.

\section{Funding:}


This study was funded by Viatris China. The study sponsor participated in the design, with no involvement in collection, analysis, and interpretation of the data, in the writing of the article, and in the decision to submit for publication.

\section{Contributions:}

Y.H. designed the paper. S.Q.L. selected the literature, extracted data, carried out the statistical analysis, produced the tables and figures, and wrote the first edition of the paper. W.Z.J selected the literature and extracted data. S.Q.L., W.Z.J., Y.N. and M.Y.F all evaluated the methodological quality of included trials. Y.L.C. and Y.H were consulted and helped to revise the manuscript. All authors contributed to the review and approval of the final manuscript.

\section{Ethics approval and consent to participate:}

Not applicable.

\section{Consent for publication:}

Not applicable.

\section{Competing interests:}

The authors declare that they have no competing interests.

\section{References}

1. Hoeper MM, Bogaard HJ, Condliffe R, Frantz R, Khanna D, Kurzyna M, Langleben D, Manes A, Satoh T, Torres F, Wilkins MR, Badesch DB. Definitions and diagnosis of pulmonary hypertension. J Am Coll Cardiol. 2013;62 Suppl 25:D42-D50. doi:10.1016/j.jacc.2013.10.032.

2. Hoeper MM, Humbert M, Souza R, Idrees M, Kawut SM, Sliwa-Hahnle K, Jing ZC, Gibbs JS. A global view of pulmonary hypertension. Lancet Respir Med. 2016;4(4):306-22. doi:10.1016/S2213-2600(15)00543-3.

3. McLaughlin VV, Archer SL, Badesch DB, Barst RJ, Farber HW, Lindner JR, Mathier MA, McGoon MD, Park MH, Rosenson RS, Rubin LJ, Tapson VF, Varga J. ACCF/AHA 2009 expert consensus document on pulmonary hypertension: a report of the American College of Cardiology Foundation Task Force on expert consensus documents. J Am Coll Cardiol. 2009;53(17):1573-619. doi:10.1016/j.jacc.2009.01.004.

4. Archer SL, Michelakis ED. Phosphodiesterase Type 5 Inhibitors for Pulmonary Arterial Hypertension. N Engl J Med. 2009;361(19):1864-71. doi:10.1056/NEJMct0904473.

5. Badesch DB, Raskob GE, Elliott CG, Krichman AM, Farber HW, Frost AE, Barst RJ, Benza RL, Liou TG, Turner M, Giles S, Feldkircher K, Miller DP, McGoon MD. Pulmonary arterial hypertension: baseline characteristics from the REVEAL Registry. Chest. 2010;137(2):376-87. doi:10.1378/chest.09-1140.

6. Hoeper MM, Simon R Gibbs J. The changing landscape of pulmonary arterial hypertension and implications for patient care. Eur Respir Rev. 2014;23(134):450-7. doi: 10.1183/09059180.00007814.

7. Peacock AJ, Murphy NF, McMurray JJ, Caballero L, Stewart S. An epidemiological study of pulmonary arterial hypertension. Eur Respir J. 2007;30(1):104-9. doi:10.1183/09031936.00092306.

8. Humbert M, Sitbon O, Chaouat A, Bertocchi M, Habib G, Gressin V, Yaici A, Weitzenblum E, Cordier JF, Chabot F, Dromer C, Pison C, Reynaud-Gaubert M, Haloun A, Laurent M, Hachulla E, Simonneau G. Pulmonary arterial 
hypertension in France: results from a national registry. Am J Respir Crit Care Med. 2006;173(9):1023-30. doi:10.1164/rccm.200510-16680C.

9. Escribano-Subias P, Blanco I, López-Meseguer M, Lopez-Guarch CJ, Roman A, Morales P, Castillo-Palma MJ, Segovia J, Gómez-Sanchez MA, Barberà JA; REHAP investigators. Survival in pulmonary hypertension in Spain: insights from the Spanish registry. Eur Respir J. 2012;40(3):596-603. doi:10.1183/09031936.00101211.

10. Delcroix M, Howard L. Pulmonary arterial hypertension: the burden of disease and impact on quality of life. Eur Respir Rev. 2015;24(138):621-9. doi:10.1183/16000617.0063-2015.

11. McLaughlin VV, Shillington A, Rich S. Survival in primary pulmonary hypertension: the impact of epoprostenol therapy. Circulation. 2002;106(12):1477-82. doi: 10.1161/01.cir.0000029100.82385.58.

12. Montani D, Chaumais MC, Guignabert C, Günther S, Girerd B, Jaïs X, Algalarrondo V, Price LC, Savale L, Sitbon 0 , Simonneau G, Humbert M. Targeted therapies in pulmonary arterial hypertension. Pharmacol Ther. 2014;141(2):172-91. doi:10.1016/j.pharmthera.2013.10.002.

13. Safdar Z. Targeted oral therapies in the treatment of pulmonary arterial hypertension. Clin Drug Investig. 2010;30(12):811-26. doi:10.2165/11538870-000000000-00000.

14. Zolty R. Pulmonary arterial hypertension specific therapy: The old and the new. Pharmacol Ther. 2020;214:107576. doi:10.1016/j.pharmthera.2020.107576.

15. Humbert M, Sitbon O, Simonneau G. Treatment of pulmonary arterial hypertension. N Engl J Med 2004;351:142536. doi:10.1056/NEJMra040291.

16. Barnes H, Brown Z, Burns A, Williams T. Phosphodiesterase 5 inhibitors for pulmonary hypertension. Cochrane Database Syst Rev. 2019;1(1):CD012621. doi:10.1002/14651858.CD012621.pub2.

17. Pulmonary vascular Disease Group, Cardiovascular Branch, Chinese Medical Association. Chinese Guidelines for the Diagnosis and Treatment of Pulmonary Hypertension 2021. Natl Med J China. 2021;101(1):11-51. doi: 3760/cma.j.cn112137-20201008-02778.

18. Galiè N, Humbert M, Vachiery JL, Gibbs S, Lang I, Torbicki A, Simonneau G, Peacock A, Vonk Noordegraaf A, Beghetti M, Ghofrani A, Gomez Sanchez MA, Hansmann G, Klepetko W, Lancellotti P, Matucci M, McDonagh T, Pierard LA, Trindade PT, Zompatori M, Hoeper M. 2015 ESC/ERS Guidelines for the Diagnosis and Treatment of Pulmonary Hypertension. Rev Esp Cardiol (Engl Ed). 2016;69(2):177. doi:10.1016/j.rec.2016.01.002.

19. Klinger JR, Elliott CG, Levine DJ, Bossone E, Duvall L, Fagan K, Frantsve-Hawley J, Kawut SM, Ryan JJ, Rosenzweig EB, Sederstrom N, Steen VD, Badesch DB. Therapy for Pulmonary Arterial Hypertension in Adults: Update of the CHEST Guideline and Expert Panel Report. Chest. 2019;155(3):565-86. doi:10.1016/j.chest.2018.11.030.

20. He CJ, Chen SJ, Wang J, Zhu CY, Yin YH. Efficacy and safety of phosphodiesterase type-5 inhibitors for pulmonary arterial hypertension: A meta-analysis focusing on 6MWD. Pulm Pharmacol Ther. 2015;32:24-8. doi:10.1016/j.pupt.2015.03.002.

21. Liu HL, Chen XY, Li JR, Su SW, Ding T, Shi CX, Jiang YF, Zhu ZN. Efficacy and Safety of Pulmonary Arterial Hypertension-specific Therapy in Pulmonary Arterial Hypertension: A Meta-analysis of Randomized Controlled Trials. Chest. 2016;150(2):353-66. doi:10.1016/j.chest.2016.03.031.

22. Xu XQ, Jing ZC, Zhang JH, Wu Y, Wang Y, Jiang X, Wang ZX, Sun YG, Pu JL, Yang YJ. The efficacy and safety of sildenafil in Chinese patients with pulmonary arterial hypertension. Hypertens Res. 2009;32(10):911-5. doi:10.1038/hr.2009.113.

23. Moher D, Liberati A, Tetzlaff J, Altman DG, The PRISMA Group. Preferred Reporting Items for Systematic Reviews and Meta-analyses: the PRISMA statement. BMJ. 2009;339:b2535. doi: https://doi.org/10.1136/bmj.b2535. 
24. Rethlefsen ML, Kirtley S, Waffenschmidt S, Ayala AP, Moher D, Page MJ, Koffel JB; PRISMA-S Group. PRISMA-S: an extension to the PRISMA Statement for Reporting Literature Searches in Systematic Reviews. Syst Rev. 2021;10(1):39. doi: 10.1186/s13643-020-01542-z.

25. Li L, Tian J, Tian H, Moher D, Liang F, Jiang T, Yao L, Yang K. Network meta-analyses could be improved by searching more sources and by involving a librarian. J Clin Epidemiol. 2014;67(9):1001-7. doi:10.1016/j.jclinepi.2014.04.003.

26. Higgins JP, Altman DG, Gøtzsche PC, Jüni P, Moher D, Oxman AD, Savovic J, Schulz KF, Weeks L, Sterne JA; Cochrane Bias Methods Group; Cochrane Statistical Methods Group. The Cochrane Collaboration's tool for assessing risk of bias in randomised trials. BMJ. 2011;343:d5928. doi:10.1136/bmj.d5928.

27. Sterne JA, Hernán MA, Reeves BC, Savović J, Berkman ND, Viswanathan M, Henry D, Altman DG, Ansari MT, Boutron I, Carpenter JR, Chan AW, Churchill R, Deeks JJ, Hróbjartsson A, Kirkham J, Jüni P, Loke YK, Pigott TD, Ramsay CR, Regidor D, Rothstein HR, Sandhu L, Santaguida PL, Schünemann HJ, Shea B, Shrier I, Tugwell P, Turner L, Valentine JC, Waddington H, Waters E, Wells GA, Whiting PF, Higgins JP. ROBINS-I: a tool for assessing risk of bias in non-randomised studies of interventions. BMJ. 2016;355:i4919. doi:10.1136/bmj.i4919.

28. Higgins JPT, Thomas J, Chandler J, Cumpston M, Li T, Page MJ, Welch VA (editors). Cochrane Handbook for Systematic Reviews of Interventions version 6.2 (updated February 2021). Cochrane, 2021. Available from training.cochrane.org/handbook.

29. Furukawa TA, Barbui C, Cipriani A, Brambilla P, Watanabe N. Imputing missing standard deviations in metaanalyses can provide accurate results. J Clin Epidemiol. 2006;59(1):7-10. doi:10.1016/j.jclinepi.2005.06.006.

30. DerSimonian R, Kacker R. Random-effects model for meta-analysis of clinical trials: an update. Contemp Clin Trials. 2007;28(2):105-14. doi:10.1016/j.cct.2006.04.004.2.

31. Galiè N, Ghofrani HA, Torbicki A, Barst RJ, Rubin LJ, Badesch D, Fleming T, Parpia T, Burgess G, Branzi A, Grimminger F, Kurzyna M, Simonneau G; Sildenafil Use in Pulmonary Arterial Hypertension (SUPER) Study Group. Sildenafil citrate therapy for pulmonary arterial hypertension. N Engl J Med. 2005;353(20):2148-57. doi:10.1056/NEJMoa050010.

32. Pepke-Zaba J, Gilbert C, Collings L, Brown MC. Sildenafil improves health-related quality of life in patients with pulmonary arterial hypertension. Chest. 2008;133(1):183-9. doi:10.1378/chest.07-0592.

33. Zhang ZN, Jiang X, Zhang R, Li XL, Wu BX, Zhao QH, Wang Y, Dai LZ, Pan L, Gomberg-Maitland M, Jing ZC. Oral sildenafil treatment for Eisenmenger syndrome: a prospective, open-label, multicentre study. Heart. 2011;97(22):1876-81. doi:10.1136/heartjnl-2011-300344.

34. Satoh T, Saji T, Watanabe H, Ogawa S, Takehara K, Tanabe N, Yamada N, Yao A, Miyaji K, Nakanishi N, Suzuki Y, Fujiwara T, Kuriyama T. A phase III, multicenter, collaborative, open-label clinical trial of sildenafil in Japanese patients with pulmonary arterial hypertension. Circ J. 2011;75(3):677-82. doi:10.1253/circj.cj-10-0671.

35. Wirostko BM, Tressler C, Hwang LJ, Burgess G, Laties AM. Ocular safety of sildenafil citrate when administered chronically for pulmonary arterial hypertension: results from phase III, randomised, double masked, placebo controlled trial and open label extension. BMJ. 2012;344:e554. doi:10.1136/bmj.e554.

36. Xu X, Qi G, Lu L, Wang L, Zhan S, Wang Q, Pang Y, Yang Y, Chen Q. Effects of transcatheter closure and Sildenafil on plasma brain natriuretic peptide in patients with ventricular septal defects combined with moderate-severe pulmonary artery hypertension. Shandong Med J, 2013;053(019):15-7. doi:10.3969/j.issn.1002266X.2013.19.005.

37. Webb DJ, Vachiery JL, Hwang LJ, Maurey JO. Sildenafil improves renal function in patients with pulmonary arterial hypertension. Br J Clin Pharmacol. 2015;80(2):235-41. doi:10.1111/bcp.12616.3.

Page $14 / 19$ 
38. Galiè N, Channick RN, Frantz RP, Grünig E, Jing ZC, Moiseeva O, Preston IR, Pulido T, Safdar Z, Tamura Y, McLaughlin VV. Risk stratification and medical therapy of pulmonary arterial hypertension. Eur Respir J. 2019;53(1):1801889. doi:10.1183/13993003.01889-2018.

39. Cukier FN, Fernandes RA, Takemoto MLS, Takemoto MMS, Fujii RK, Mould JF. Efficacy and Safety of Sildenafil Above 60 mg Daily in Pulmonary Arterial Hypertension Treatment-a Systematic Literature Review. Value Health. 2011;14(7):488. doi: 10.1016/j.jval.2011.08.1394.

40. Igarashi A, Inoue S, Ishii T, Tsutani K, Watanabe H. Comparative Effectiveness of Oral Medications for Pulmonary Arterial Hypertension. Int Heart J. 2016;57(4):466-72. doi:10.1536/ihj.15-459.

41. Wang Y, Zhang X. Efficacy of Sildenafil Therapy in Pulmonary Artery Hypertension: A Meta-Analysis. J Evid Base Med. 2014;014(003):160-5. doi:10.3969/j.issn.1671-5144.2014.03.008.

42. Kuang TG, Wang J, Zhai ZG, Guo XH, Wang C. Efficacy and safety of sildenafil therapy in pulmonary artery hypertension: a meta-analysis. Natl M ed J China. 2007,87(15):1021-4. doi:10.3760/j:issn:03762491.2007.15.004.

43. Jing Z. Clinical application of six-minute walk distance text. Chin J Cardiol. 2006;34(4):381-4. doi:10.3760/j:issn:0253-3758.2006.04.032.

\section{Figures}



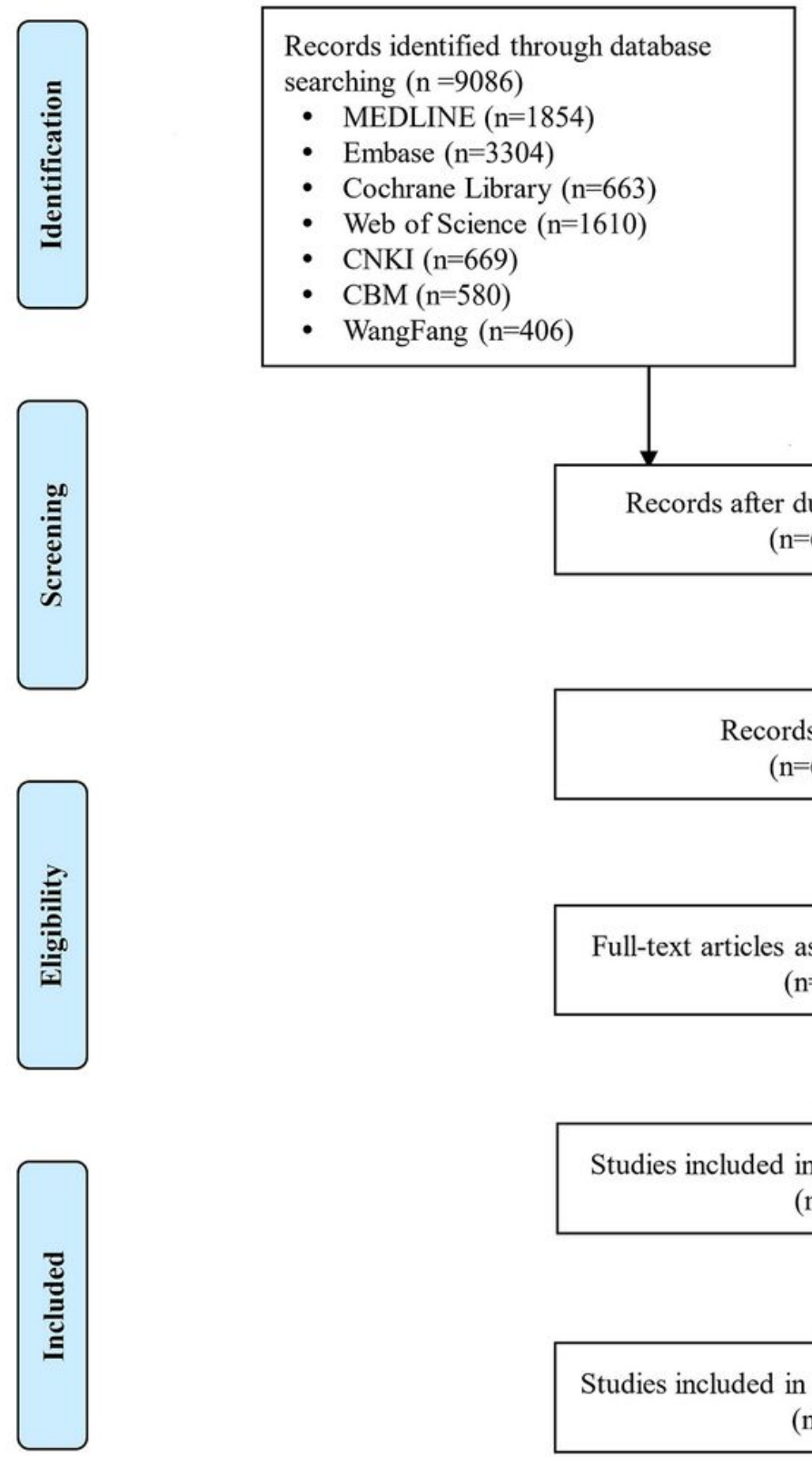

Additional records identified through other sources $(\mathrm{n}=3)$

- Clinical trial registry platforms $(\mathrm{n}=0)$

- Google Scholar $(n=3)$

- Reference lists of retrieved articles $(\mathrm{n}=0)$

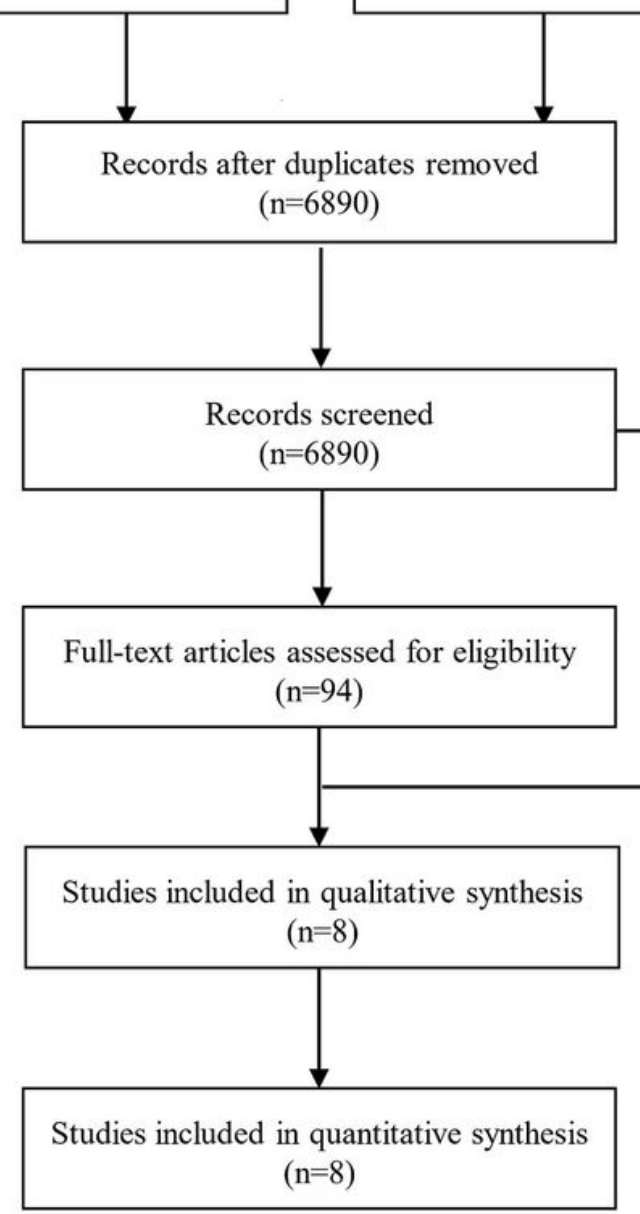

Records excluded ( $\mathrm{n}=6796)$

\section{Figure 1}

Flow diagram of the literature search

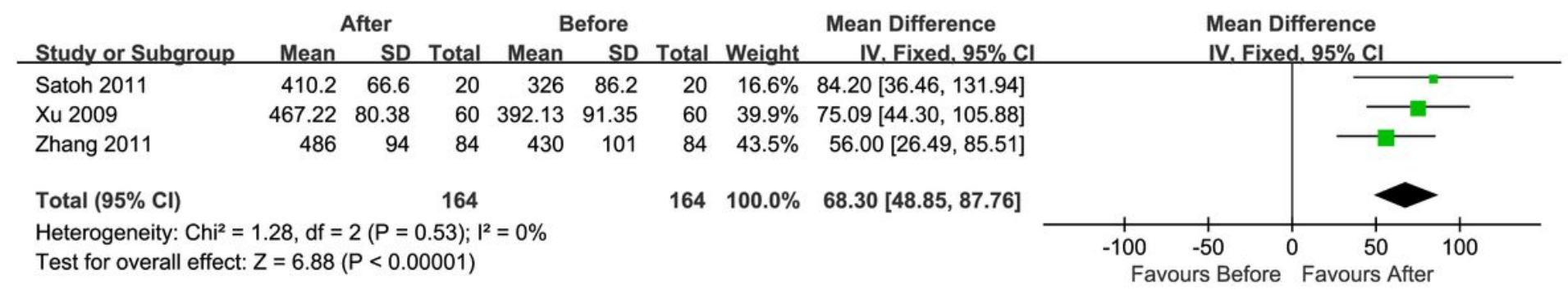

\section{Figure 2}

Forest plot of $6 \mathrm{MWD}$ comparing sildenafil with symptomatic treatment 


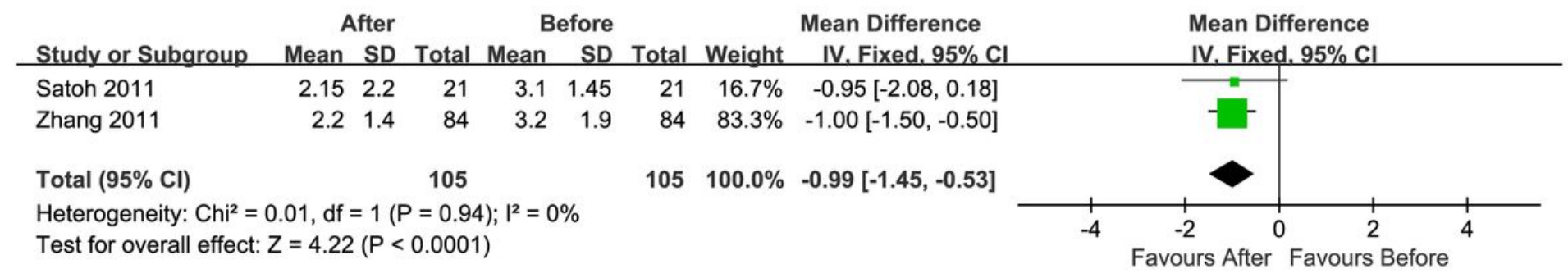

\section{Figure 3}

Forest plot of dyspnoea score comparing sildenafil with symptomatic treatment

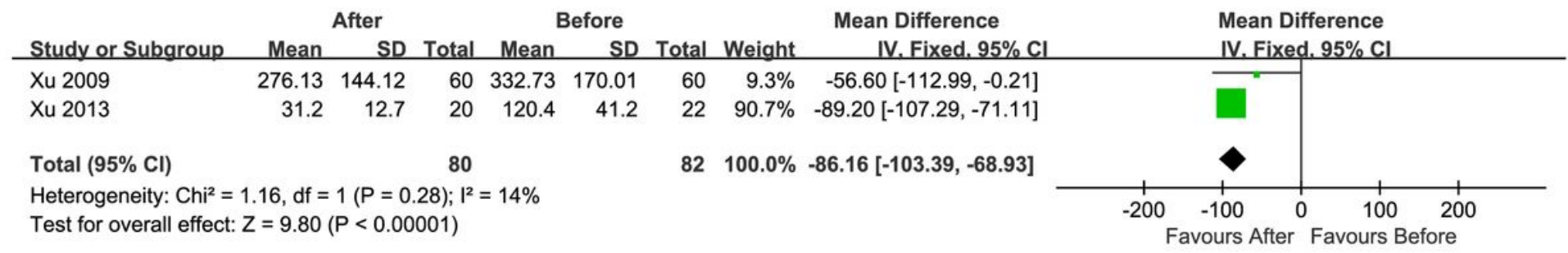

\section{Figure 4}

Forest plot of BNP comparing sildenafil with placebo or symptomatic treatment

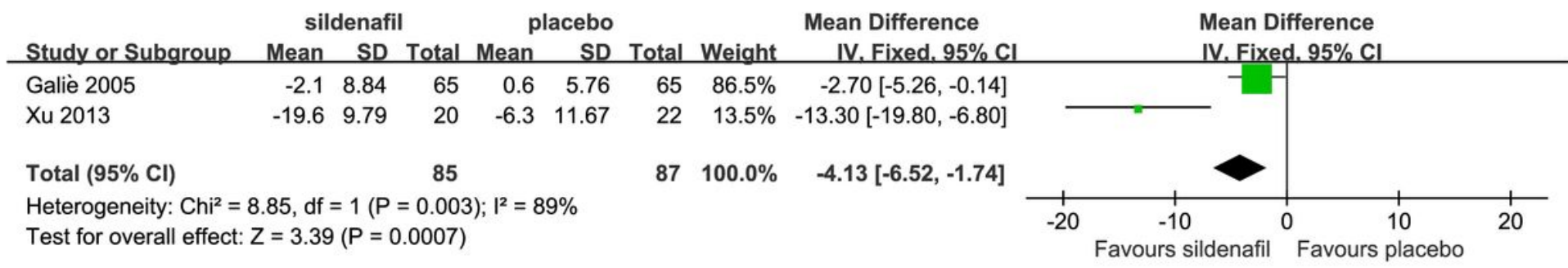

\section{Figure 5}

Forest plot of reduction in mean PAP comparing sildenafil with placebo

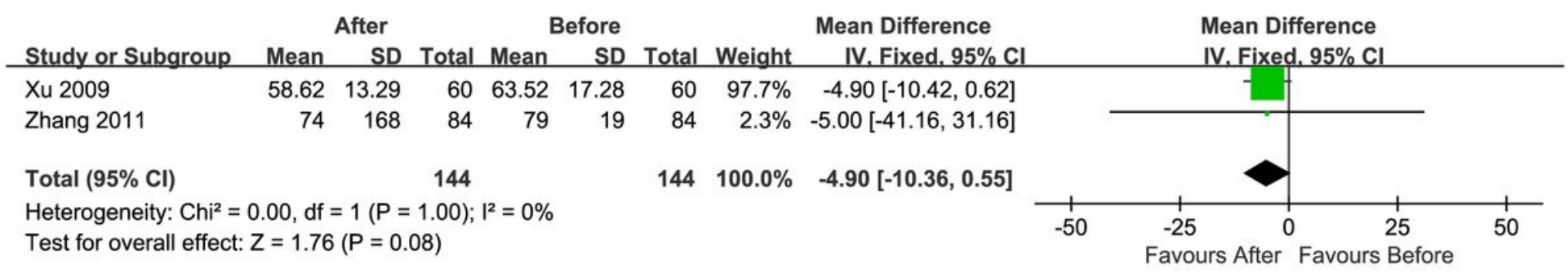

\section{Figure 6}

Forest plot of mean PAP comparing sildenafil with symptomatic treatment 


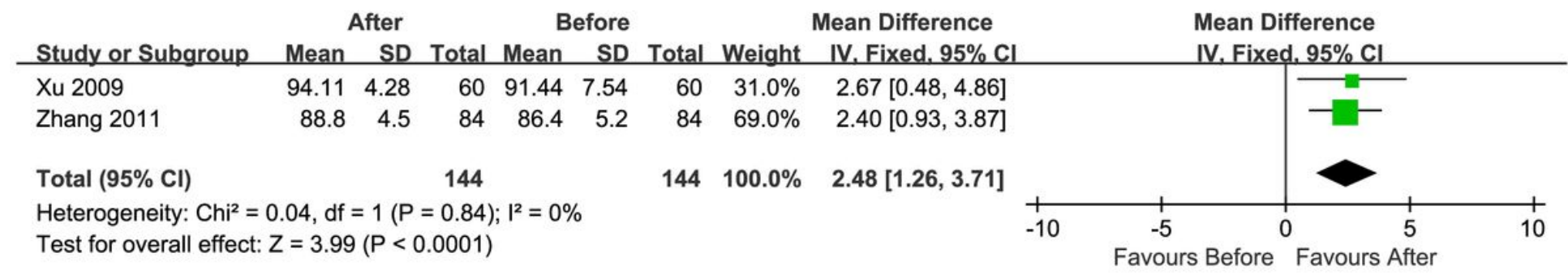

\section{Figure 7}

Forest plot of systemic arterial oxygen saturation comparing sildenafil with symptomatic treatment

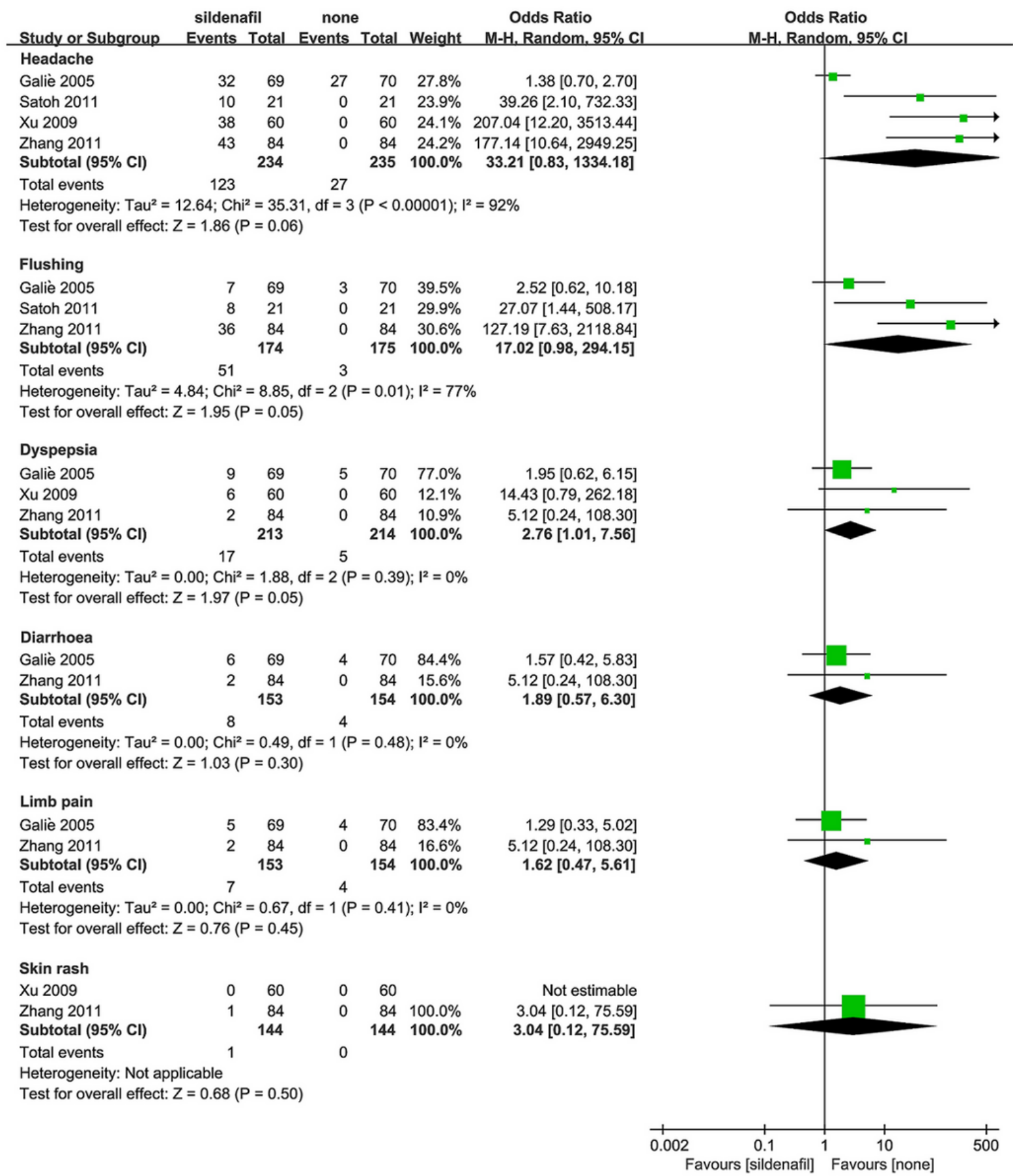


Forest plot of adverse events

\section{Supplementary Files}

This is a list of supplementary files associated with this preprint. Click to download.

- Additionalfile1forPRISMAchecklist.pdf

- Additionalfile2forSearchStrategies.docx

- Additionalfile3forRiskofbiasassessment.docx 